\title{
Immediately downstream effects of Three Gorges Dam on channel sandbars morphodynamics between Yichang-Chenglingji Reach of the Changjiang River, China
}

\author{
WANG Jie ${ }^{1},{ }^{*}$ DAI Zhijun ${ }^{1,2}$, MEI Xuefei ${ }^{1}$, LOU Yaying ${ }^{1}$, WEI Wen ${ }^{1}$, GE Zhenpeng ${ }^{1}$ \\ 1. State Key Laboratory of Estuarine and Coastal Research, East China Normal University, Shanghai 200062, \\ China; \\ 2. Laboratory for Marine Geology, Qingdao National Laboratory for Marine Science and Technology, Qingdao, \\ 266061, China
}

\begin{abstract}
Sandbars are of vital ecological and environmental significance, which however, have been intensively influenced by human activities. Morphodynamic processes of sandbars along the Yichang-Chenglingji Reach of the Changjiang River, the channel immediately downstream of the Three Gorges Dam (TGD), are assessed based on remote sensing images between 2000 and 2016 . It can be found that the entire area of sandbars reduces drastically by $19.23 \%$ from $149.04 \mathrm{~km}^{2}$ in 2003 to $120.38 \mathrm{~km}^{2}$ in 2016 , accompanied with an increase in water surface width. Owing to differences in sediment grain size and anti-erosion capacity, sandbar area in the upstream sandy gravel reach (Yichang-Dabujie) and downstream sandy reach (Dabujie-Chenglingji) respectively decreases by $45.94 \%$ (from $20.79 \mathrm{~km}^{2}$ to $11.24 \mathrm{~km}^{2}$ ) and $14.93 \%$ (from $128.30 \mathrm{~km}^{2}$ to $109.14 \mathrm{~km}^{2}$ ). Furtherly, morphological evolutions of sandbars are affected by channel type: in straight-microbend channel, mid-channel sandbars exhibit downstream moving while maintaining the basic profile; in meandering channel, point sandbars show erosion and deposition in convex and concave bank respectively, with mid-channel sandbars distributing sporadically; in bending-branching channel, point sandbars experience erosion and move downstream while mid-channel sandbars show erosion in the head part along with retreating outline. We document that the primary mechanism of sandbars shrinkages along the Yichang-Chenglingji Reach can be attributed to TGD induced suspended sediment concentration decreasing and increasing in unsaturation of sediment carrying capacity. Additionally, channel type can affect the morphological evolution of sandbars. Along the Yichang-Chenglingji Reach, sandbars in straight-microbend channel are more affected by water flow than that in bending-branching channel.
\end{abstract}

Received: 2017-09-08 Accepted: 2017-12-07

Foundation: National Natural Science Foundation of China, No.41576087; National Science Foundation for Young Scientists of China, No.41706093; Fund of the Key Laboratory of Coastal Science and Engineering, Beibu Gulf, Guangxi, No.2016ZZD01

Author: Wang Jie, Master Candidate, specialized in fluvial and estuarine morphodynamics. E-mail: jiewang.ec@gmail.com "Corresponding author: Dai Zhijun, $\mathrm{PhD}$ and Professor, specialized in estuarine and coastal morphodynamics. 
Keywords: sandbars morphodynamics; Three Gorges Dam (TGD); remote sensing images; Yichang-Chenglingji Reach; Changjiang River

\section{Introduction}

A variety of alluvial sandbars are formed by riffle accumulations, floodplain avulsions, degradation of channel branches, and incision of existing bars (Knighton and Nanson, 1993; Xu, 1997; Wyrick and Klingeman, 2011), which undertake critical hydraulic and environmental functions, including stabilizing channel configurations, regulating floods and providing valuable habitats for a large number of organisms (Bridge, 1993; Ashworth et al., 2000). However, sandbars are one of the most threatened river geomorphological features as they are suffering from direct and accumulative hydrodynamic impacts (Kearsley et al., 1994; Phillips et al., 2005; Francis et al., 2010; Raška et al., 2017). Markedly, with the release of large-scale low suspended sediment concentration (SSC) flows from upstream dams, sandbars geomorphological systems can experience serious degradation in the channel immediately downstream of the dam (Petts, 1979; Friedman et al., 1998; Brandt, 2000a; Grams and Schmidt, 2005; Kleinhans et al., 2011). Understanding sandbars morphodynamics in response to water projects and the associated formation mechanisms is extremely pivotal critical and urgent for hydraulic engineering, channel regulation and fluvial management (Friedman et al., 1998; Graf, 2005; Magilligan and Nislow, 2005; Wyrick and Klingeman, 2011; Asaeda and Rashid, 2012; Dai et al., 2014; Grabowski and Gurnell, 2016).

To investigate how channel sandbars geomorphological processes respond to dam and reservoir construction, Petts (1979) reviewed potential sandbars variations subsequent to changes in discharge and bed-sediment load along multiple British rivers. Phillips et al. (2005) documented that the decreased channel slope and degradation in sandbars morphology can be attribute to the dam induced sediment supply decline with unchanged discharge regime. Raška et al. (2017) indicated that sediment starvation and erosion following the construction of dams and lock chambers caused island extinction in individual river segments. Generally, river sandbars formation and destruction are directly related with the dam induced downstream channel features variation, which have received special attentions in Britain (Petts, 1979), Australia (Erskine, 1985), New South Wales (Sherrard and Erskine, 1991), Bangladesh (Ashworth et al., 2000), American rivers (Graf, 2006; Hazel et al., 2006; Csiki and Rhoads, 2010; Skalak et al., 2013), Spain (Ibisate et al., 2013), France (Provansal et al., 2014) and Czech (Raška et al., 2017) rivers. Fluvial channel and drainage basin are critical zone of earth surface processes, especially for those immediately downstream of large dams. However, little information is available on the sandbars morphodynamics along the mega-river of Changjiang (Yangtze) River in China, which are regulated by Three Gorges Dam (TGD) since 2003, currently the world's largest water conservancy dam.

The Changjiang River originates from the Qinghai-Tibet Plateau and flows eastward into the East China Sea, with a length more than $6300 \mathrm{~km}$ (Figure 1a). The catchment covers an area of over $1.8 \times 10^{6} \mathrm{~km}^{2}$ and includes multitudinous geomorphological, vegetation and tributary types (Dai and Liu, 2013; Wei et al., 2014). Since June 2003, the TGD has trapped vast majority of sediment in its reservoir, without significantly modifying downstream flow magnitude (Dai et al., 2015). Thus coupling of drastically decreased suspended sediment concentration (SSC) and discharge (SSD) with almost unchanged water discharge produces 
remarkable erosion in the downstream riverbed (Yang et al., 2011; Mei et al., 2016; Dai et al., 2016). Xu and Milliman (2009) revealed that about 60\% of SSD was trapped behind TGD during 2003-2006, which caused substantial erosion in the mainstream and Dongting Lake. Chang et al. (2010) estimated that the scouring amount along Jing River (Zhicheng to Chenglingji) accounts for $78.9 \%$ of that along the entire reach from Yichang to Chenglingji within 2003-2008. Luo (2012) found an abrupt longitudinal transition of sand-gravel of river bed sediment in the middle and lower Yangtze River during the post-TGD period. Meanwhile, Yuan (2012) documented that the most obvious scour occurred immediately adjacent to the TGD, due to the increased potential capacity of sediment carrying and transporting. Dai and Liu (2013) indicated that 10 years after TGD operation, channel down cutting along the thalweg throughout the river course and riverbed would be transformed from depositional before the dam construction to erosional afterwards. Yang et al. (2014) demonstrated that the alluvial and meandering channels along the mid-lower Changjiang River presented downcutting trends due to TGD impoundment. Zhang et al. (2017) showed that fluvial coarse and fine sand was restored in 2003-2014 after the construction of TGD, since river channels experienced scouring for supply new alluvial sediment.

Even though extensive studies have been carried out on the response of downstream sediment-geomorphology system to TGD induced fluvial hydrodynamic changes, few attentions are related to the evolution of sandbars morphodynamics along the Yichang-Chenglingji (YC) Reach immediately downstream of the TGD (Figure 1b). The YC Reach of the Changjiang River covers a large-scale of multiple sandbars (Figure 1b), which are sensitive to the complex changes in hydro-sediment dynamics due to the establishment of TGD. Thereafter, synthetic data of hydrology, suspended sediment and multi-remote satellite images are utilized to detect the sandbars morphodynamics along the YC Reach of the Changjiang River. The main aims of this study, therefore, are to: (1) explore the spatial-temporal characteristics of sandbars along the YC Reach; (2) discern their possible morphodynamics patterns; (3) identify the potential factors that may influence the morphodynamic processes of sandbars.

\section{Research setting and methods}

\subsection{Study area}

Immediately downstream of the TGD, YC Reach is located in the upper half of the Changjiang River's middle reach, and it is where the river transforms from bedrock gorge to alluvial plain (Xia et al., 2016) (Figure 1a). Alluvial sandbars along the YC Reach are diversified, which can be classified as point bars and mid-channel bars, according to their developmental locations and patterns. Specifically, point bars and mid-channel bars respectively developed along the river bank and surrounded by the ambient flow, and can be converted to one another (Hooke, 1986; Birkeland, 1996; Wright and Kaplinski, 2011). According to the channel sediment composition and river shape, the YC Reach can be further divided into two sections: the upstream sandy gravel reach (Yichang-Dabujie) and the downstream sandy reach (Dabujie-Chenglingji) (Figure 1b). Specifically, the sandy gravel reach is composed of gravel sand, where the channel plane configuration and shoal landform remain basically stable (Yu and Lu, 2008; Chen et al., 2010; Xia et al., 2016). The sandy reach flows through the Jianghan and Dongting Lake alluvial plains, consisting of fine and medium sand, where channel patterns are meandering and branching with multiple point and mid-channel sand- 
bars (Wang et al., 2009; Xia et al., 2014). The upstream sandy gravel reach mainly contains straight-microbend and bending-branching channel, while the downstream sandy reach is primarily composed by straight-microbend, meandering and bending-branching channel. The above channel patterns are classified according to the regional river regime and channel morphology from upstream to downstream. Moreover, the YC Reach discharges a fraction of water-sediment load to Dongting Lake through Songzikou, Taipingkou and Ouchikou, while obtaining water and sediment flux from the lake through Chenglingji (Figure 1b).
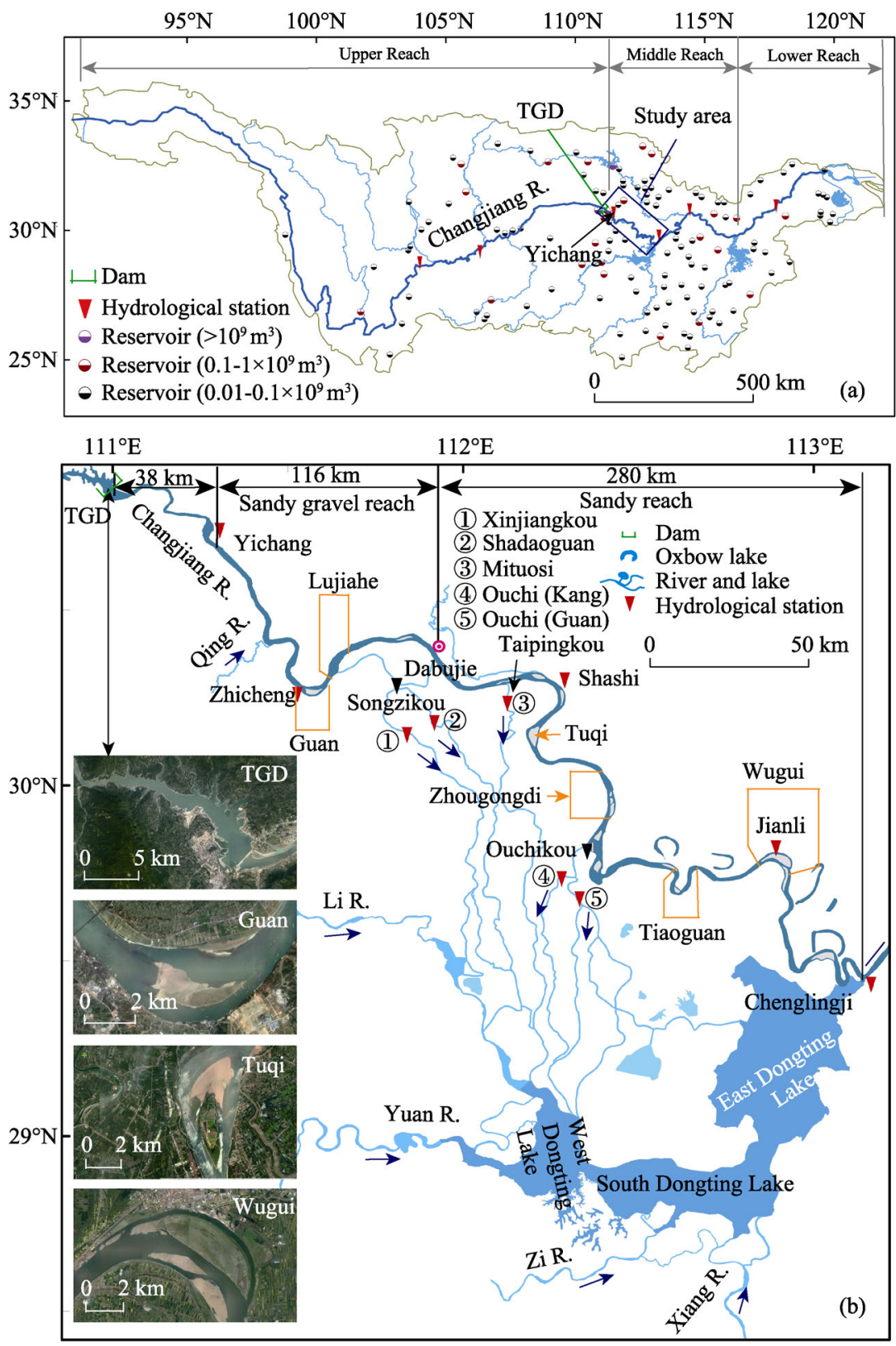

Figure 1 Map of the study area. (a) The location of Changjiang River and Yichang-Chenglingji Reach (blue box); (b) the Yichang-Chenglingji Reach. Four inserted satellite images indicate TGD and three typical sandbars are acquired from Google Earth map (http://www.google.cn/maps) 


\subsection{Data collection}

The synthesis database of hydrology, sediment and multi-temporal Landsat satellite images can be further divided into two groups as follows:

The first group contains water discharge, SSC, flow velocity and sediment grain size measurements at Yichang, Zhicheng, Shashi and Jianli hydrologic stations (including measured and calculated values) (Figure 1b) between 1990 and 2014, covering the pre-TGD and post-TGD periods. These data were obtained from Bulletin of China River Sediment (http://www.cjw.gov.cn/).

The second group consists of remote-sensing images. Annual Landsat8 satellite images during 2000 to 2016 are acquired to examine the morphological evolution of sandbars through quantitative inversions, with occasional vacancy in 2012 and 2013 due to clouds (Table 1). Landsat images that correspond to similar water level in the dry season are selected to accurately describe the evolutions of alluvial sandbars. All available Landsat OLI (Operational Land Imager), TM (Thematic Mapper) and ETM+ (Enhanced Thematic Mapper Plus) imageries are downloaded from United States Geological Survey/Earth Resources Observation and Science Center (USGS/EROS) (https://www.usgs.gov/). A total of 16 standard Level 1 Terrain-Corrected products are obtained in this study.

Table 1 Summary of Landsat satellite products and corresponding water level (m) at four hydrologic stations

\begin{tabular}{cccccc}
\hline Date & Sensor & Yichang & Zhicheng & Shashi & Jianli \\
\hline Feb. 01, 2000 & Landsat7 ETM+ & 39.53 & 37.65 & 31.70 & 24.21 \\
Jan. 10, 2001 & Landsat5 TM & 40.15 & 38.20 & 32.79 & 25.13 \\
Jan. 05, 2002 & Landsat7 ETM+ & 39.68 & 38.80 & 32.22 & 24.74 \\
Mar. 21, 2003 & Landsat5 TM & 38.92 & 37.45 & 31.24 & 25.72 \\
Mar. 07, 2004 & Landsat5 TM & 40.49 & 38.66 & 32.96 & 25.82 \\
Feb. 22, 2005 & Landsat5 TM & 38.63 & 37.42 & 30.86 & 26.07 \\
Feb. 25, 2006 & Landsat5 TM & 40.15 & 38.26 & 32.20 & 25.57 \\
Feb. 12,2007 & Landsat5 TM & 39.01 & 37.62 & 30.78 & 24.37 \\
Feb. 15, 2008 & Landsat5 TM & 39.02 & 37.73 & 31.16 & 24.60 \\
Jan. 16, 2009 & Landsat5 TM & 39.35 & 37.98 & 31.72 & 24.93 \\
Feb. 20, 2010 & Landsat5 TM & 39.31 & 37.88 & 31.31 & 24.98 \\
Jan. 06, 2011 & Landsat5 TM & 39.73 & 38.20 & 31.82 & 25.62 \\
Jan. 14, 2014 & Landsat8 OLI & 39.85 & 38.08 & 31.62 & 25.38 \\
Jan. 01, 2015 & Landsat8 OLI & 39.63 & 37.97 & 31.56 & 25.50 \\
Feb. 05, 2016 & Landsat8 OLI & 39.99 & 38.16 & 31.34 & 26.30 \\
\hline
\end{tabular}

\subsection{Methods}

\subsubsection{Satellite image interpretation}

Satellite remote sensing images and geostatistical methods have been widely adopted to explore terrain transformation analyses (Jiang et al., 2011, 2015a, 2015b; Tang et al., 2014, 2016; Messager et al., 2016). Preprocessing operations of Landsat images are all conducted via the software of Environment for Visualizing Images (ENVI), mainly through the tools of Radiometric Calibration and Fast Line-of-Sight Atmospheric Analysis of Spectral Hyper- 
cubes (FLAASH) Atmosphere Correction.

In this study, a modified normalized difference water index (MNDWI) is utilized to determine the geomorphology of mid-channel and point sandbars (Xu, 2006; Soti et al., 2009), which has been applied to identify waterbodies developments, reveal vegetation changes, environmental predictors, coastline changes and so on (Hui et al., 2008; Sun et al., 2012; Ullah et al., 2013; Tran et al., 2014; Ghosh et al., 2015). MNDWI differentiates sandbars terrestrial geomorphology from other physical features like water bodies through:

$$
\text { MNDWI }=(\text { Green }- \text { MIR }) /(\text { Green }+ \text { MIR })
$$

where MNDWI is modified normalized difference water index, Green and MIR respectively represents a green and middle infrared band, such as TM bands 2 and 5. The MNDWI of water bodies has a higher value than other terrestrial covers like built-up land, soil and vegetation, because the spectral reflectance in the infrared wavelengths of water bodies is the lowest and significantly less than that in green band. Based on the MNDWI results and a proper threshold (distinct natural breakpoints of frequency distributions), the surface feature of the YC Reach can be categorized into sandbars and other surficial objects. Classification processes and corresponding statistics are accomplished by Esri-ArcGIS (Environment System Research Institute-Arc Geographic Information System) 10.2 software.

Once the area of total sandbars, mid-channel and point sandbars are obtained, they can be further analyzed using classified statistics technique. To study sandbars morphodynamics in detail, the YC Reach is divided into 500 subsections. For each subsection, its transverse centerline is extracted firstly, which thereafter excludes the section that covering the point and mid-channel sandbars, can be set as the subsection's water surface width (WSW). The sum of WSW of all 500 subsections is set as total water surface width (TWSW).

\subsubsection{Sediment carrying capacity}

The classical theories of sediment carrying capacity (SCC) (Qian and Wan, 2003), that has been well applied to the Changjiang River by a certain of previous researchers (Yu et al., 2005; Li et al., 2011; Yuan et al., 2012), was adopted in this study to illustrate the downstream hydro-sediment processes. The related formulas are shown as follows:

$$
\begin{gathered}
S_{v m}=k\left(U^{3} / g h \omega\right)^{m} \\
\omega=\left(1-S_{v}\right)^{2.239} \omega_{0} \\
\omega_{0}=1.72 \sqrt{\frac{\rho_{s-} \rho_{w}}{\rho_{w}} g D}
\end{gathered}
$$

where $S_{v m}$ is the suspended sediment carrying capacity (necessary SSC in balance); $k$ and $m$ are constants, in this study they are set as 0.07 and 1.14, respectively; $U$ is water velocity; $g$ is gravitational acceleration $\left(9.8 \mathrm{~m} / \mathrm{s}^{2}\right)$; $h$ is water depth; $\omega$ is sediment settling velocity; $S_{v}$ is $\mathrm{SSC} ; \omega_{0}$ is setting velocity of given sediment with diameter $D$ and density $\rho_{s}\left(2650 \mathrm{~kg} / \mathrm{m}^{3}\right)$, $\rho_{w}$ is water density $\left(1000 \mathrm{~kg} / \mathrm{m}^{3}\right)$. Water velocity, water depth and SSC corresponding to various discharge scenarios for each year are calculated through power function fitting techniques. Moreover, the difference (unsaturation) between calculated $S_{v m}$ and measured SSC can reflect the morphodynamic condition along the downstream channel, when positive and negative value respectively indicates scour and deposition condition. 
TGD starts to impound water in the June of 2003, therefore, the time series of 1990-2002 and 2003-2014 are respectively set to indicate the pre- and post-TGD stage. Note that the remote sensing image of 2003 is generated in March, which, accordingly describes the sandbars morphology in pre-TGD stage.

\section{Results}

\subsection{Changes of sandbar area between the Yichang-Chenglingji Reach}

The total area of sandbars within the YC Reach decreases by $19.23 \%$ from $149.04 \mathrm{~km}^{2}$ in pre-TGD $(03,2003)$ to $120.38 \mathrm{~km}^{2}$ in 2016 (Figure 2a). While the point sandbars exhibits a similar observable decreasing trend in area from $109.65 \mathrm{~km}^{2}$ in 2003 to $86.49 \mathrm{~km}^{2}$ in 2016 (Figure $2 \mathrm{~b}$ ), the mid-channel sandbars only indicate a slight area decrease of $5.52 \mathrm{~km}^{2}$ over the same period (Figure 2c). Moreover, the upstream sandy gravel reach and downstream sandy reach show variant changing degrees in sandbars area. Specifically, the total sandbar area in the sandy gravel reach has a sharp decline from $20.79 \mathrm{~km}^{2}$ in 2003 to $11.24 \mathrm{~km}^{2}$ in 2016 (Figure 3a) while that in the sandy reach shows a greater erosion amount from $128.30 \mathrm{~km}^{2}$ in 2003 to $109.14 \mathrm{~km}^{2}$ in 2016 (Figure 3d). The area of mid-channel bars decreases substantially in the upstream reach but has no observable variation in the downstream reach (Figures $3 \mathrm{~b}$ and 3e). At the same time, the area of point bars in the downstream reach exhibits a more significant decreasing trend than that of the upstream reach (Figures $3 \mathrm{c}$ and $3 \mathrm{f}$ ). The multi-year average areas of total, mid-channel and point sandbars respectively decreased by $8.73 \%, \quad 7.72 \%$ and $9.10 \%$ from 2000-2003 to 2004-2016 (Table 2). It needs to be stressed that the entire area of sandbars in the upstream reach only accounts for $20 \%$ of that in the downstream reach and appears a decreasing trend year by year (Figures 3a and 3d). Besides, TWSW along the entire reach, upstream sandy gravel reach and downstream sandy reach all exhibit significantly widening tendency, expending respectively by $9.29 \%, 9.73 \%$ and $9.10 \%$ from pre-TGD stage to 2016 (Figure 4 and Table 3). This means that the decrease of sandbar area has widened the TWSW to a certain extent.

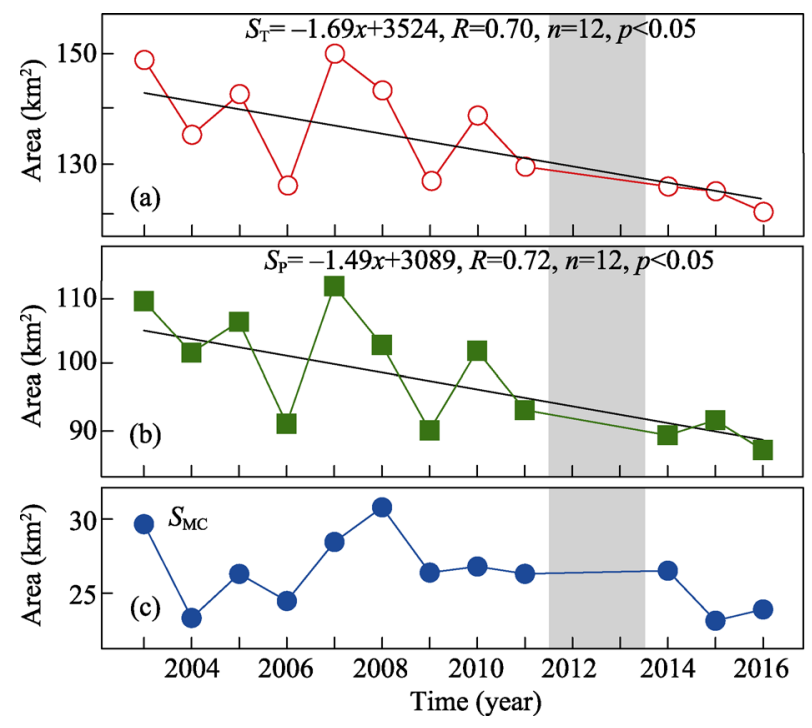

Figure 2 Temporal variation of sandbar area within Yichang-Chenglingji Reach from 2003 to 2016. (a) $\mathrm{S}_{\mathrm{T}}$ : total sandbars; (b) $\mathrm{S}_{\mathrm{MC}}$ : mid-channel sandbars; and (c) $\mathrm{S}_{\mathrm{P}}$ : point sandbars. The year with grey rectangle indicating data missing

\subsection{Geomorphological changes of sandbars along the upstream sandy gravel reach}

The upstream sandy gravel reach mainly consists of two types of channel pattern, namely, bending-branching and straight-microbend channel. In this study, Guanzhou Channel and Liujiahe Channel are selected to characterize the geomorphological evolution of bending-branching 

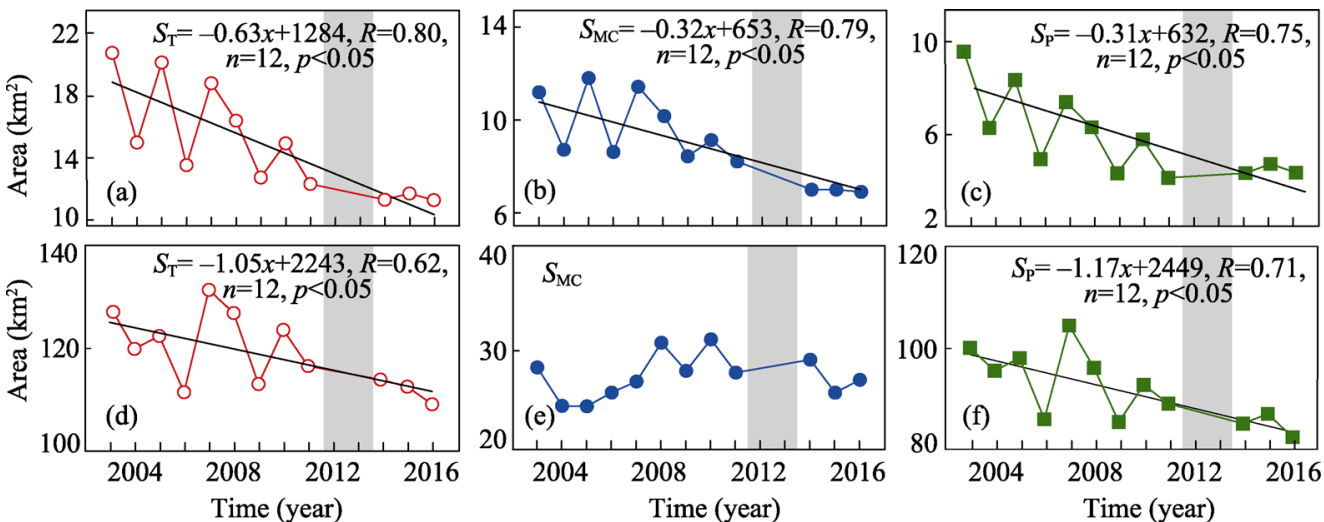

Figure 3 Temporal variation of sandbar area in (a-c) the upstream sandy gravel reach and (e-f) the downstream sandy reach, with $\mathrm{S}_{\mathrm{T}}, \mathrm{S}_{\mathrm{MC}}$, and $\mathrm{S}_{\mathrm{P}}$ respectively indicating areas of total sandbars, mid-channel sandbars and point sandbars. The year with grey rectangle indicating data missing

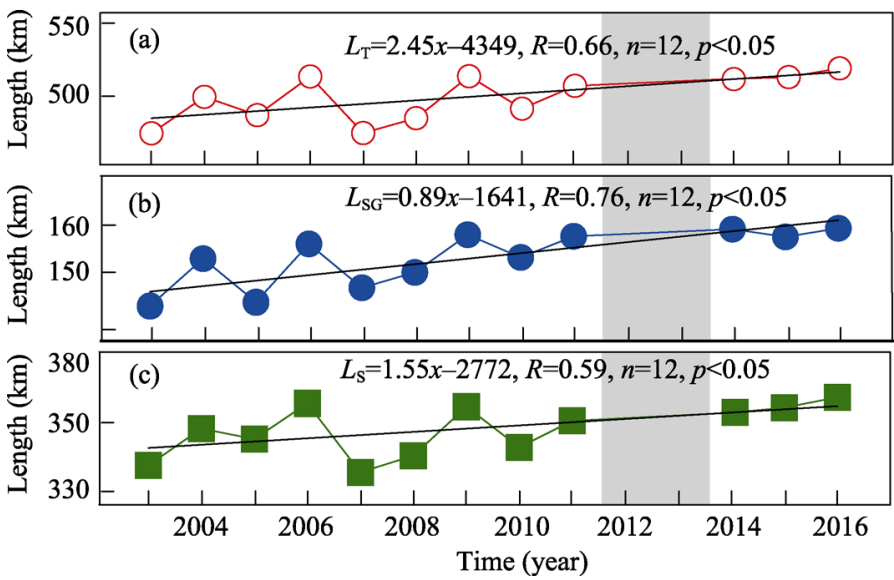

Figure 4 Temporal variation of the total water surface width (TWSW) of (a) the Yichang-Chenglingji Reach $\left(\mathrm{L}_{\mathrm{T}}\right)$; (b) the upstream sandy gravel reach $\left(\mathrm{L}_{\mathrm{SG}}\right)$; and (c) the downstream sandy reach $\left(\mathrm{L}_{\mathrm{S}}\right)$. The year with grey rectangle indicating data missing

Table 2 Summary of sandbar area variation within the Yichang-Chenglingji Reach

\begin{tabular}{|c|c|c|c|c|c|c|c|c|c|}
\hline & \multicolumn{3}{|c|}{ Area of total $\left(\mathrm{km}^{2}\right)$} & \multicolumn{3}{|c|}{ Area of mid-channel $\left(\mathrm{km}^{2}\right)$} & \multicolumn{3}{|c|}{ Area of point $\left(\mathrm{km}^{2}\right)$} \\
\hline Reach & Whole & $\begin{array}{l}\text { Sandy } \\
\text { gravel }\end{array}$ & Sandy & Whole & $\begin{array}{l}\text { Sandy } \\
\text { gravel }\end{array}$ & Sandy & Whole & $\begin{array}{l}\text { Sandy } \\
\text { gravel }\end{array}$ & Sandy \\
\hline Before TGD & 145.35 & 20.45 & 126.75 & 38.93 & 10.73 & 26.31 & 106.42 & 10.08 & 100.45 \\
\hline After TGD & 132.66 & 12.55 & 107.14 & 35.93 & 7.79 & 25.07 & 96.73 & 4.77 & 82.06 \\
\hline Decrease $(\%)$ & 8.73 & 38.65 & 15.47 & 7.72 & 24.86 & 4.69 & 9.10 & 52.84 & 18.31 \\
\hline
\end{tabular}

Note: pre-TGD: mean value between 2000 and 2003; post-TGD: mean value between 2004 and 2016

Table 3 Summary of channel width variation within the Yichang-Chenglingji Reach

\begin{tabular}{cccc}
\hline & Total reach $(\mathrm{km})$ & Sandy gravel reach $(\mathrm{km})$ & Sandy reach $(\mathrm{km})$ \\
\hline Before TGD & 479.90 & 143.48 & 336.42 \\
After TGD & 501.51 & 152.98 & 348.53 \\
Increase (\%) & 4.50 & 6.62 & 3.60 \\
\hline
\end{tabular}

Note: Before TGD: mean value between 2000 and 2003; After TGD: mean value between 2004 and 2016 
and straight-microbend channels, which are respectively located $70 \mathrm{~km}$ and $85 \mathrm{~km}$ downstream of Yichang (Figure 1b).

In Guanzhou Channel, the areas of sandbars, point-sandbars and mid-channel sandbars all show marked decreases from 2003 to 2013 and become stable thereafter. Specifically, point sandbars are located in the left bank of the channel with a serrated shape in 2003, which moves to the downstream thereafter and develops to an arc shape because of water erosion. In 2016, there is only a small scale of point sandbars remaining along the lower part of the left bank (Figures 5a-5d). The mid-channel sandbars appear to be spinning with an indented head in the initial stage at 2003, which move approximately 600-800 m downstream entirely in the following 14 years with its spindle contour becomes smaller. Correspondingly, the water width ratio between the left and right branch decreases from 0.92 in 2003 to 0.6 in 2016 .

The straight-microbend Lujiahe Channel experiences sharp decrease in the area of sandbars, point sandbars as well as mid-channel bars during 2003-2016 (Figure 6). The channel contains a set of loosely coupled mid-channel sandbars and relatively rich point sandbars along the right bank between 2003 and 2006 (Figure 6a). In the following years from 2006-2008, the mid-channel sandbars exhibit considerable decrease both in numbers and areas (Figures 6b-6d). For instance, the area of the largest mid-channel sandbar reduces from $2.70 \mathrm{~km}^{2}$ to $1.66 \mathrm{~km}^{2}$ while a number of small mid-channel sandbars are completely disappeared. Meanwhile, the remaining mid-channel sandbars become relatively smooth owing to water erosion. Over the period of 2009-2011, the largest mid-channel sandbar turns to a slender shape while the point sandbar is further shirking (Figures $6 \mathrm{c}$ and $6 \mathrm{~d}$ ). In 2016, there are only two mid-channel sandbars left each with an area smaller than $0.15 \mathrm{~km}^{2}$ while the outline of the point sandbars runs almost parallel to the right bank.

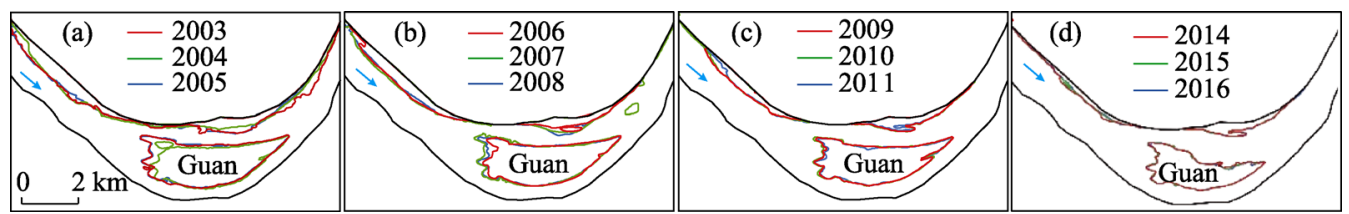

Figure 5 Sandbars geomorphological changes within Guanzhou Channel from 2003 to 2016
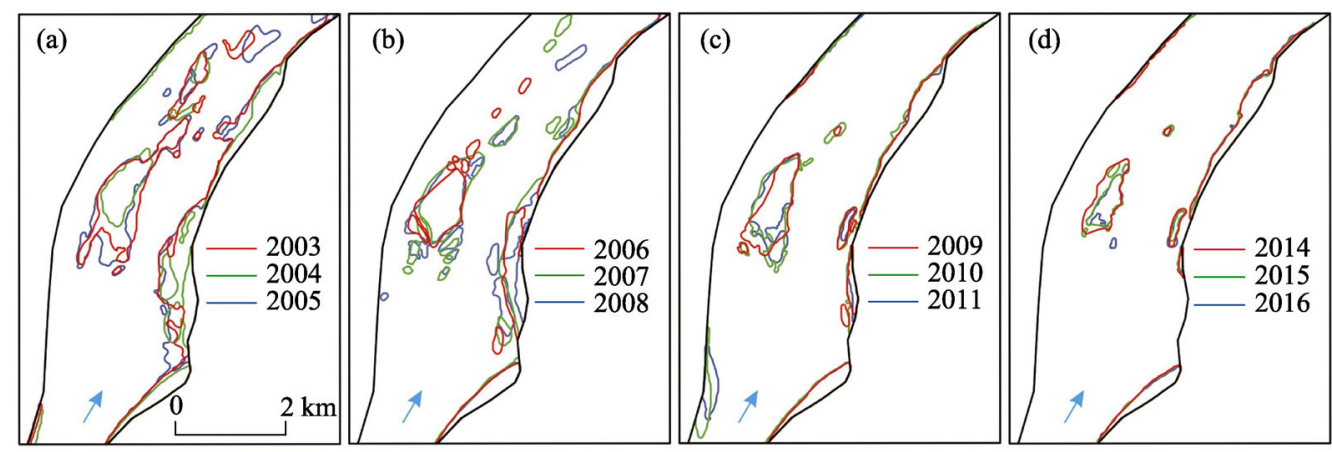

Figure 6 Sandbars geomorphological changes within Lujiahe Channel from 2003 to 2016

\subsection{Geomorphological changes in sandbars along downstream sandy reach}

There are three basic types of channel patterns along the downstream sandy reach: straight-microbend, meandering and bending-branching channel, which are analyzed in de- 
tail in three representative channels. Zhougongdi Channel, locating $245 \mathrm{~km}$ downstream of Yichang, is a typical straight-microbend channel. Sandbars along the Zhougongdi channel are made up of two mid-channel sandbars with a total area of $1.43 \mathrm{~km}^{2}$ and a fusiform point sandbar along the left bank in 2003 (Figure 7a). The two mid-channel sandbars are divided into 3-4 smaller sandbars in 2005 (Figure 7a). In the following year of 2006, there are only two mid-channel bars left, one has a small area of $0.04 \mathrm{~km}^{2}$ while the other one is adjacent to the point sandbar (Figures 7b-7d). Two line-like mid-channel sandbars appear during 2007 to 2009, which, however, disappear later in 2010 (Figures 7b-7d). Thus only a point sandbar existed in the Zhougongdi Channel since 2010.
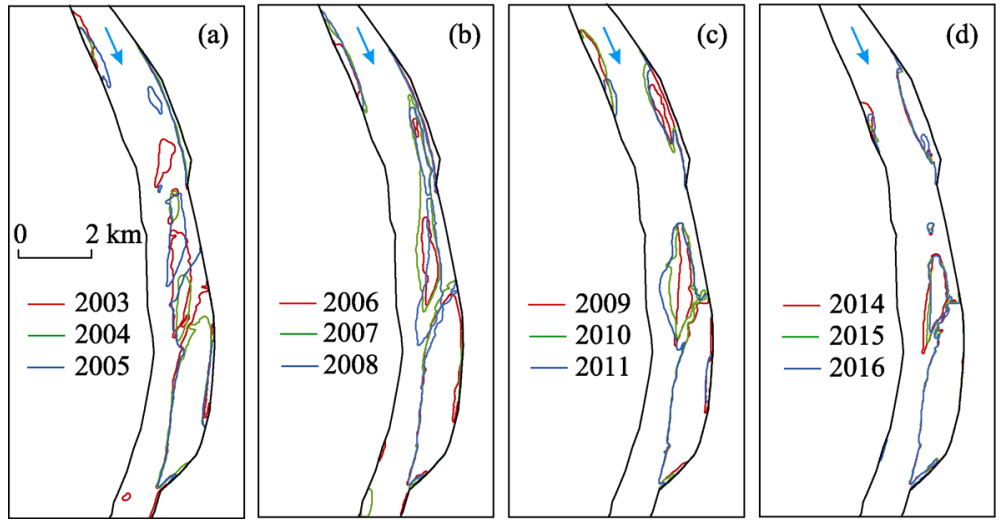

Figure 7 Geomorphological changes of sandbars within Zhougongdi Channel from 2003 to 2016

The meandering Tiaoguan Channel is located $300 \mathrm{~km}$ downstream of Yichang, with a large amount of point sandbars developed along its banks. The relatively large point sandbar along the convex bank suffers from extensive erosion during the past decade, with the area decreasing from $2.76 \mathrm{~km}^{2}$ in 2003 to $1.62 \mathrm{~km}^{2}$ in 2016 and the shoreline retreating $500 \mathrm{~m}$ (Figure 8). The long and narrow sandbar along the concave bank is relative stable during 2003-2005, followed by a considerable incision thereafter (Figure 8a). In 2008, due to the deposition of upstream sediment, there is a new mid-channel sandbar appear, with an area of $0.31 \mathrm{~km}^{2}$ (Figure $8 \mathrm{~b}$ ). Meanwhile, the point sandbars along the channel entrance gradually grow larger and continually generate small mid-channel sandbars (Figures $8 \mathrm{c}$ and $8 \mathrm{~d}$ ). A large scale of mid-channel sandbars is developed ultimately during 2014-2016, when, on the contrary, point sandbars continuously experiencing erosion along the concave bank. At the same time, new point sandbar is generated along the left bank of the lower reach, which develops gradually to the downstream (Figures $8 \mathrm{c}$ and $8 \mathrm{~d}$ ).

Jianli Channel is located $340 \mathrm{~km}$ downstream of Yichang, which is a typical example of bending-branching channel. At the initial stage of 2003, there are four mid-channel sand
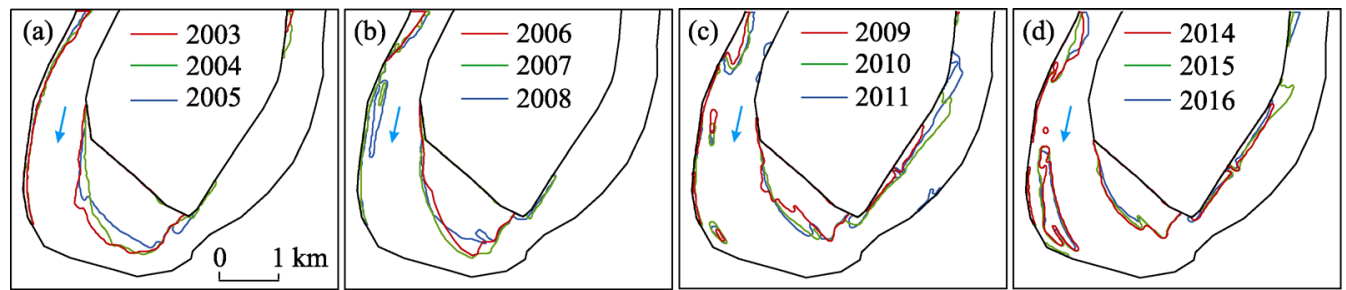

Figure 8 Geomorphological changes of sandbars within Tiaoguan Channel from 2003 to 2016 
bars along the channel, with the largest Wugui Shoal covering an area of $8.87 \mathrm{~km}^{2}$. The total area of sandbars decreases from $13.14 \mathrm{~km}^{2}$ in 2003 to $11.59 \mathrm{~km}^{2}$ in 2005 , when the small mid-channel sandbars are fully sourced (Figure 9a). From 2005 to 2009, a certain amount of sediment deposit along the concave bank of the channel entrance, with scared sandbars developing in terms of both mid-channel sandbars and point sandbars (Figure 9b). During this period, Wugui Shoal merges with the adjacent mid-channel sandbars, with the head developing to upstream. In the meantime, significant deposition occurs along the point sandbars that adjacent to the convex bank. In the rest 7 years from 2009 to 2016, sediment deposition continues along the left bank of the channel entrance, characterized by appearance of new sandbar (Figures 9c and 9d). While Wugui Shoal develops upstream further, the sandbars along the convex bank reaches a stable state after multiple incision and migration. Moreover, the outline of Wugui Shoal exhibits a drastic retreat of $240 \mathrm{~m}$ in the tail part. Small sandbars along the concave bank of the channel exit are completely eroded (Figure 9). Apparently, the channel branches develop with the evolution of mid-channel and point sandbars (Figure 9).
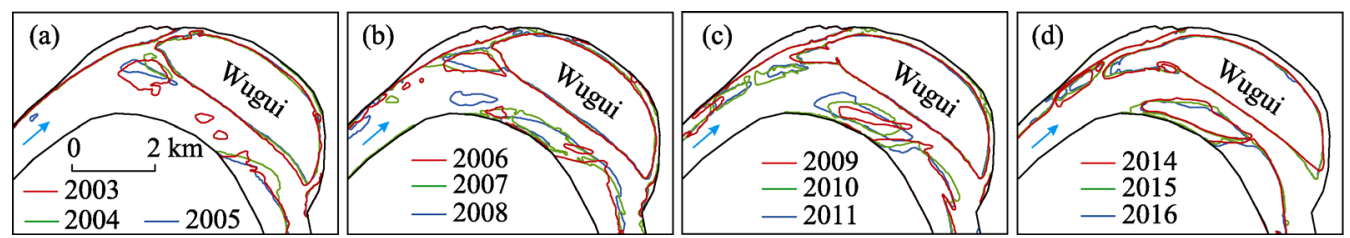

Figure 9 Geomorphological changes of sandbars within Jianli Channel from 2003 to 2016

\section{Discussion}

\subsection{Impacts from water and suspended sediment discharge}

Annual water discharges at the four stations along the YC Reach are relatively stable during 1990-2014, except the year of 2006, when an extreme drought occurs, indicating mild impacts from TGD impoundment (Figure 10a) (Yang et al., 2015; Zhao et al., 2015). Compared with those at Yichang and Zhicheng, water discharges at Shashi and Jianli are relatively small because of water diversion into Dongting Lake (Figures 10a and 1b) (Zhu et al., 2014; Li et al., 2015). However, the post-TGD SSC series show abrupt declines at all hydrometric stations, down $89.43 \%, 87.46 \%, 83.19 \%$ and $77.17 \%$, respectively, in comparison with the pre-TGD period (Figure 10b). TGD impoundment induced sharp decreases in SSD coupled with relatively stable discharge can generate hungry (starving) water along the reach downstream of the dam, which trigger erosion of the riverbed as well as sandbars (Brandt, 2000b; Yang et al., 2011; Raška et al., 2017). The erosion tendency can be also detected in the grain size of SSD and riverbed sediment grading (Wang et al., 2009; Yang et al., 2016). For instance, in the downstream sandy reach, as the coarser sediment along the riverbed is swept to the discharge, the $\mathrm{SSD}_{50}$ at Shashi and Jianli respectively increases from $0.012 \mathrm{~mm}$ and $0.009 \mathrm{~mm}$ during $1990 \mathrm{~s}-2002$ to $0.024 \mathrm{~mm}$ and $0.059 \mathrm{~mm}$ during 2003-2012 (Figure $10 \mathrm{c})$.

\subsection{Mechanisms of sandbars morphodynamics variation}

TGD regulation generates starving water along the downstream and a much smaller SSC in contrast to pre-TGD stage (Xu et al., 2013; Yang et al., 2014). In this study, Yichang hydrological 


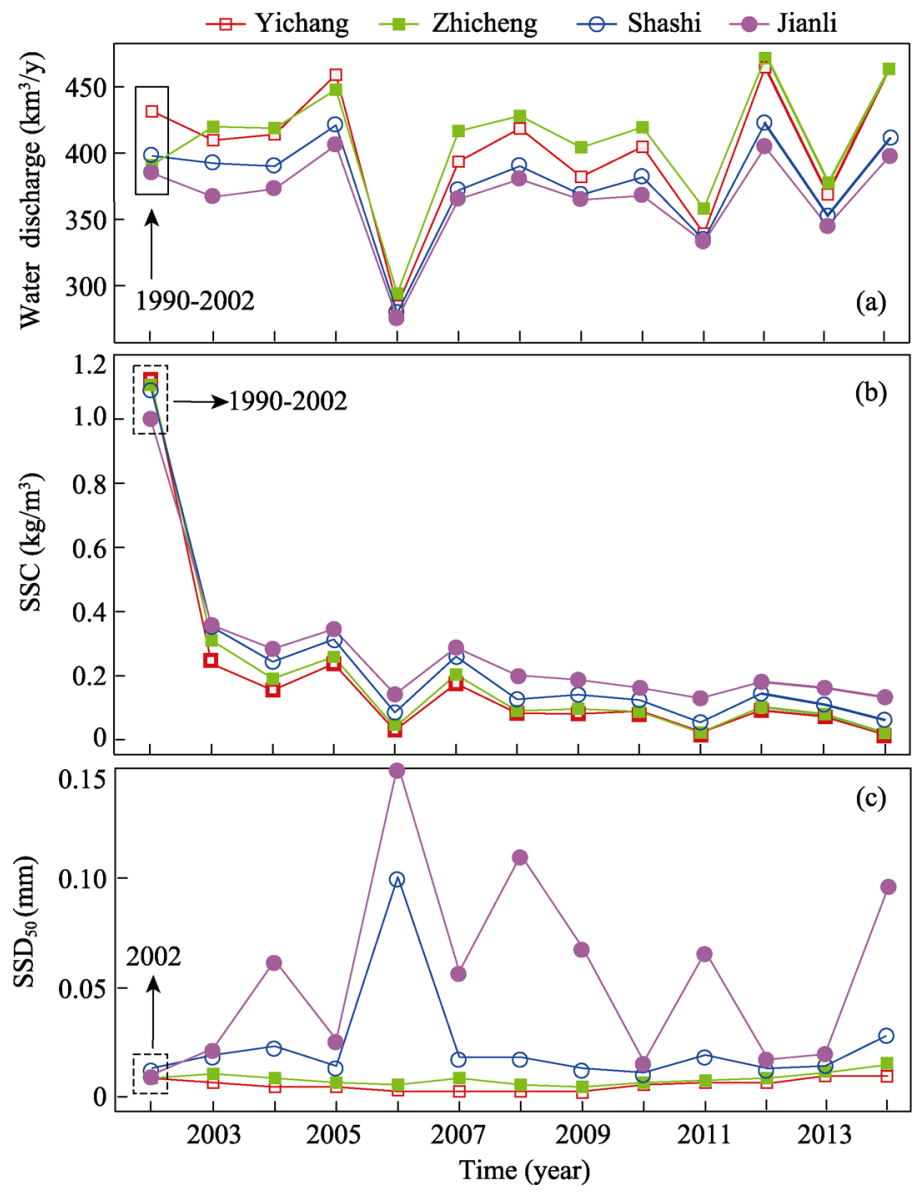

Figure 10 Temporal variation of (a) annual water discharge; (b) SSC; and (c) suspended sediment median diameter $\left(\mathrm{D}_{50}\right)$ at four hydrological stations of Yichang, Zhicheng, Shashi, and Jianli

station was selected to detect changes in unsaturation of sediment carrying capacities from 2003 to 2014 under different discharge scenarios, which can represent the reach that immediately downstream of the TGD because their water and sediment transport processes are similar after the impoundment of the TGD. SCC corresponding to dry $\left(5000 \mathrm{~m}^{3} / \mathrm{s}\right)$, normal $\left(10000 \mathrm{~m}^{3} / \mathrm{s}\right)$ and flood $\left(20000 \mathrm{~m}^{3} / \mathrm{s}\right)$ scenarios are further calculated in this section. The relationships between flow discharge and flow velocity, water depth and SSC show similar fitting characteristics at different water discharge scenarios (Figure 11). It can be found that SCC respectively increases from $0.046 \mathrm{~kg} / \mathrm{m}^{3}$ to $0.12 \mathrm{~kg} / \mathrm{m}^{3}$ (dry scenario), from $0.17 \mathrm{~kg} / \mathrm{m}^{3}$ to $0.32 \mathrm{~kg} / \mathrm{m}^{3}$ (normal scenario) and from $0.90 \mathrm{~kg} / \mathrm{m}^{3}$ to $1.00 \mathrm{~kg} / \mathrm{m}^{3}$ (flood scenario), namely, an increase of $157 \%, 86 \%$ and $12 \%$ (Figures $12 \mathrm{a}-12 \mathrm{c}$ ). Furthermore, the difference between calculated SCC and measured SSC series exhibit consistent statistical significant increase for the three scenarios $(p<0.05)$ (Figures $12 \mathrm{~d}-12 \mathrm{f}$ ). The significant negative relationship between sandbar area and SCC shows that SCC increase is likely to decrease the sandbar area (Figure 13), indicating that sandbars within downstream channel was scoured when the measured SSC is less than calculated SCC (Brandt, 2000b; Grant et al., 2003; Phillips et al., 2005; Graf, 2006; Xiong et al., 2010; Yuan et al., 2012). 

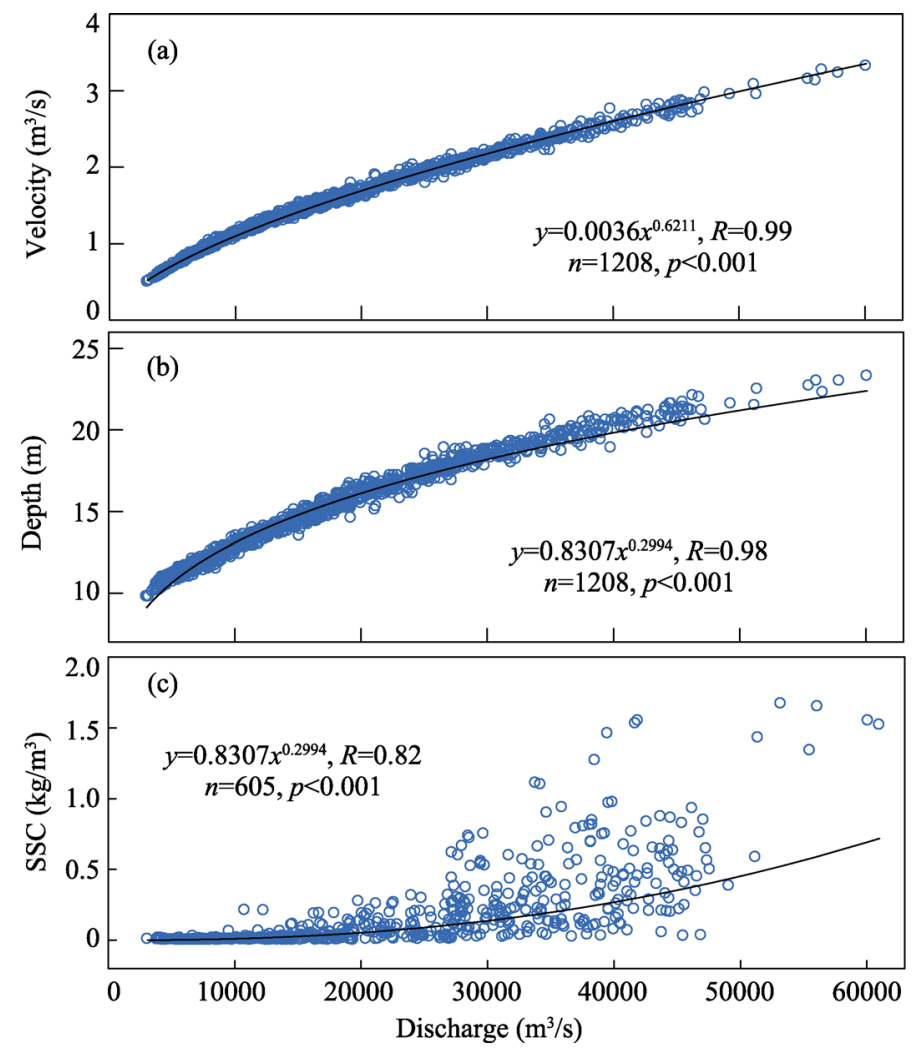

Figure 11 Relationship between flow discharge and (a) flow velocity; (b) water depth and (c) SSC
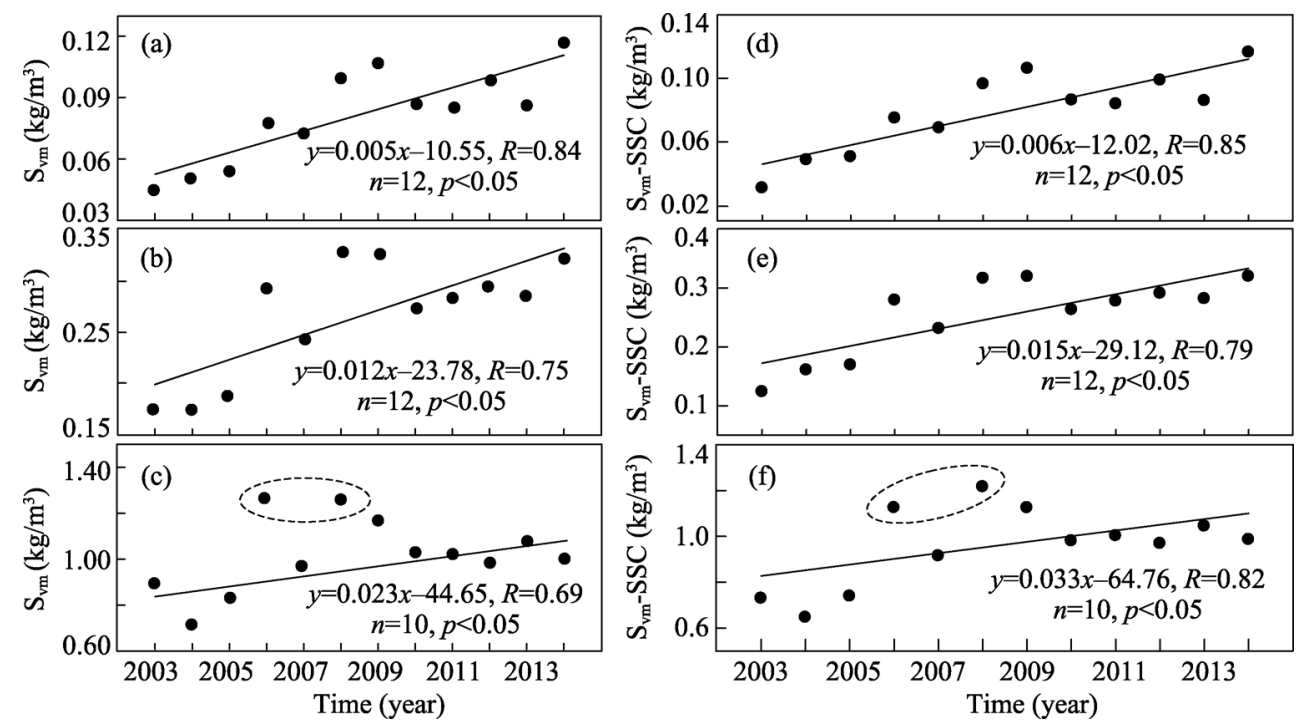

Figure 12 Temporal variation of (a-c) calculated sediment carrying capacity $\left(\mathrm{S}_{\mathrm{vm}}\right)$ and $(\mathrm{d}-\mathrm{e})$ the difference between calculated SCC and SSC ( $\mathrm{S}_{\mathrm{vm}}$-SSC) under different water discharge scenarios, with (a, d) $5000 \mathrm{~m}^{3} / \mathrm{s} ;(\mathrm{b}, \mathrm{e})$ $10000 \mathrm{~m}^{3} / \mathrm{s} ;$ (c, f) $20000 \mathrm{~m}^{3} / \mathrm{s}$

\subsection{Impacts from multiple channel patterns}

While TGD induced SCC variation causes substantial riverbed erosion along the area downstream 


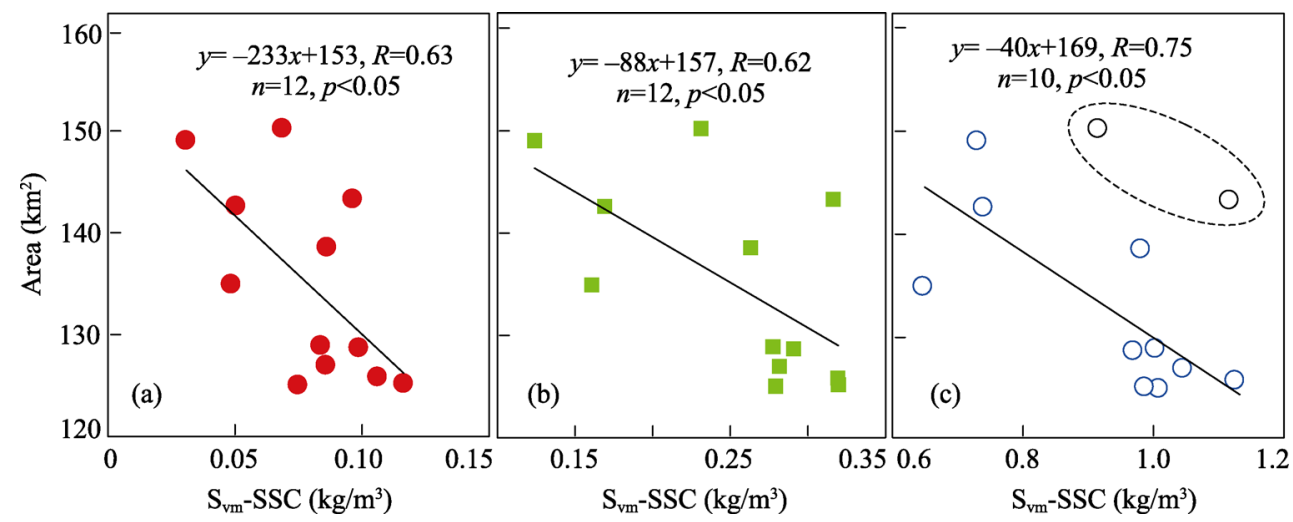

Figure 13 Relationship between sandbar area and $\mathrm{S}_{\mathrm{vm}}-\mathrm{SSC}$ value under different water discharges scenarios: (a) $5000 \mathrm{~m}^{3} / \mathrm{s}$; (b) $10000 \mathrm{~m}^{3} / \mathrm{s}$; (c) $20000 \mathrm{~m}^{3} / \mathrm{s}$

of TGD (Yuan et al., 2012), channel morphology can also affect the morphodynamic evolution of sandbars to some extent, for establishing a new dynamic equilibrium process (Petts, 1975; Xu, 1997; Grams and Schmidt, 2005; Ibisate et al., 2013; Xia et al., 2017). In the straight-microbend channel, mid-channel sandbars suffer more severely erosion in comparison with the other types of channel because of sustained current scouring while its configuration remains basically unchanged (Figure 14a). In the meandering channel, the area of point sandbars along the convex bank decreases gradually because of hungry water erosion while its outline becomes smoother gradually. Meanwhile, the scoured sediment moves to downstream and deposits along the concave bank of the lower reach (Figure 14b). In the bending-branching channel, mid-channel sandbars indicate considerable erosion and thus retreat downstream owing to the flow branching. Point sandbars along the banks are scoured simultaneously because of current erosion (Figure 14c). Besides, riverbed sediment can affect the sandbar area to a certain degree (Sherrard and Erskine, 1991; Hazel et al., 2006; Wang et al., 2009; Brandt, 2000a; Luo et al., 2012). For example, the upstream sandy gravel reach shows a stronger anti-erosion capacity than the downstream sandy reach, and as a result, its sandbars suffer relatively weak erosion.

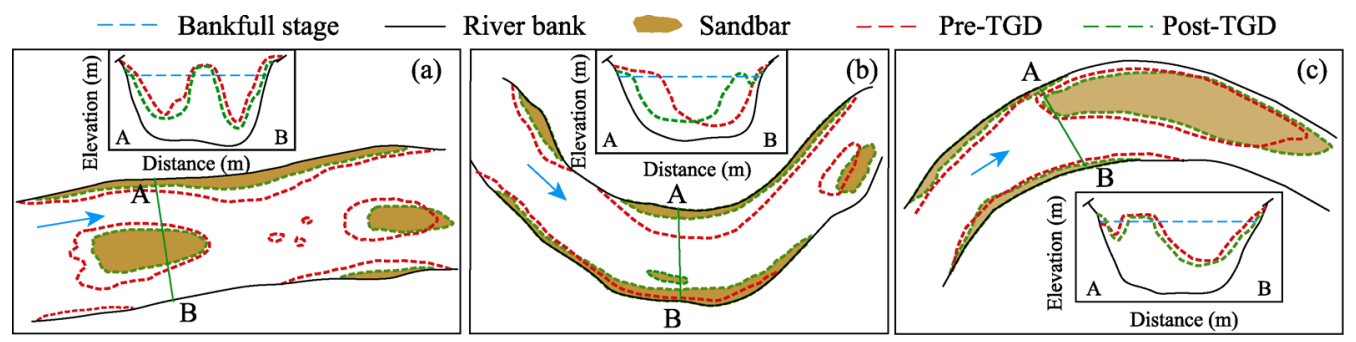

Figure 14 Evolution model of sandbars in different channel types along the Yichang-Chenglingji Reach following the impact of TGD: (a) straight-microbend channel; (b) meandering channel; and (c) bending-branching channel

\section{Conclusions}

River mid-channel and point sandbars provide critical and foundational functions for fluvial geomorphology and channel configuration stabilizing. However, sandbars along the Chang- 
jiang River has been significantly affected by the regulation of TGD, currently the world's largest hydrologic engineering. Here the morphodynamics of the sandbars along the Yichang-Chenglingji Reach, immediately downstream of TGD is firstly assessed with the main conclusions shown as follows:

(1) Sandbar area along the Yichang-Chenglingji Reach decreases from $149.04 \mathrm{~km}^{2}$ in 2003 to $120.38 \mathrm{~km}^{2}$ in 2016 , with the areas of point sandbars and mid-channel sandbars respectively decreases by $14.00 \%$ and $21.12 \%$. Furtherly, sandbar area in the upstream sandy gravel reach decreases by $45.96 \%$ while that in downstream sandy reach decreases by $14.93 \%$ following the construction of TGD.

(2) Sandbars in different channel types exhibit different morphological features: midchannel sandbars in straight-microbend channel exhibit downstream migrating, but maintain a basic profile; point sandbars in meandering channel respectively show erosion and deposition in the convex and concave banks with a certain mid-channel sandbars distributing sporadically; point sandbars in bending-branching channels experience erosion and downstream migrating while mid-channel sandbars show erosion in the head part.

(3) Three Gorges Dam induced remarkable unsaturation of sediment carrying capacity, which is the primary mechanism for sandbars scouring and shrinkage along the Yichang-Chenglingji Reach. Channel pattern can affect the geomorphological evolutions of sandbars to a certain extent, as sandbars in straight-microbend channels are more sensitive to water flow than bending-branching channels.

\section{References}

Asaeda T, Rashid M H, 2012. The impacts of sediment released from dams on downstream sediment bar vegetation. Journal of Hydrology, 430(8): 25-38.

Ashworth P J, Best J L, Roden J E et al., 2000. Morphological evolution and dynamics of a large, sand braid-bar, Jamuna River, Bangladesh. Sedimentology, 47(3): 533-555.

Birkeland G H, 1996. Riparian vegetation and sandbar morphology along the lower Little Colorado River, Arizona. Physical Geography, 17(6): 534-553.

Brandt S A, 2000a. Prediction of downstream geomorphological changes after dam construction: A stream power approach. International Journal of Water Resources Development, 16(3): 343-367.

Brandt S A, 2000b. Classification of geomorphological effects downstream of dams. Catena, 40(4): 375-401.

Chang J, Li J B, Lu D Q et al., 2010. The hydrological effect between Jingjiang River and Dongting Lake during the initial period of Three Gorges Project operation. Journal of Geographical Sciences, 20(5): 771-786.

Chen Z Y, Wang Z H, Finlayson B et al., 2010. Implications of flow control by the Three Gorges Dam on sediment and channel dynamics of the middle Yangtze (Changjiang) River, China. Geology, 38(11): 1043-1046.

Csiki S, Rhoads B L, 2010. Hydraulic and geomorphological effects of run-of-river dams. Progress in Physical Geography, 34(2): 755-780.

Dai Z J, Fagherazzi S, Mei X F et al., 2016. Decline in suspended sediment concentration delivered by the Changjiang (Yangtze) River into the East China Sea between 1956 and 2013. Geomorphology, 268: 123-132.

Dai Z J, Liu J T, 2013. Impacts of large dams on downstream fluvial sedimentation: An example of the Three Gorges Dam (TGD) on the Changjiang (Yangtze River). Journal of Hydrology, 480(4): 10-18.

Dai Z J, Liu J T, Wei W et al., 2014. Detection of the Three Gorges Dam influence on the Changjiang (Yangtze River) submerged delta. Scientific Reports, 4: 6600.

Dai Z J, Liu J T, Xiang Y B, 2015. Human interference in the water discharge of the Changjiang (Yangtze River), china. Hydrological Sciences Journal, 60(10): 1770-1782. 
Erskine W D, 1985. Downstream geomorphic impacts of large dams: The case of Glenbawn Dam, NSW. Applied Geography, 5(3): 195-210.

Francis B A, Francis L K, Cardenas M B, 2010. Water table dynamics and groundwater-surface water interaction during filling and draining of a large fluvial island due to dam-induced river stage fluctuations. Water Resources Research, 46(7): 7513.

Friedman J M, Osterkamp W R, Scott M L et al., 1998. Downstream effects of dams on channel geometry and bottomland vegetation: Regional patterns in the Great Plains. Wetlands, 18(4): 619-633.

Ghosh M K, Kumar L, Roy C, 2015. Monitoring the coastline change of Hatiya Island in Bangladesh using remote sensing techniques. ISPRS Journal of Photogrammetry and Remote Sensing, 101(101): 137-144.

Grabowski R C, Gurnell A M, 2016. Hydrogeomorphology-ecology interactions in river systems. River Research and Applications, 32(2): 139-141.

Graf W L, 2005. Geomorphology and American dams: The scientific, social, and economic context. Geomorphology, 71(1): 3-26.

Graf W L, 2006. Downstream hydrologic and geomorphic effects of large dams on American rivers. Geomorphology, 79(3): 336-360.

Grams P E, Schmidt J C, 2005. Equilibrium or indeterminate? Where sediment budgets fail: Sediment mass balance and adjustment of channel form, Green River downstream from Flaming Gorge Dam, Utah and Colorado. Geomorphology, 71(1): 156-181.

Grant G E, Schmidt J C, Lewis S L, 2003. A Geological Framework for Interpreting Downstream Effects of Dams on Rivers. American Geophysical Union.

Hazel J E, Topping D J, Schmidt J C et al., 2006. Influence of a dam on fine-sediment storage in a canyon river. Journal of Geophysical Research: Earth Surface, 111(F1): 272-288.

Hooke J M, 1986. The significance of mid-channel bars in an active meandering river. Sedimentology, 33(6): $839-850$.

Hui F M, Xu B, Huang H B et al., 2008. Modelling spatial-temporal change of Poyang Lake using multitemporal Landsat imagery. International Journal of Remote Sensing, 29(20): 5767-5784.

Ibisate A, Díaz E, Ollero A et al., 2013. Channel response to multiple damming in a meandering river, middle and lower Aragón River (Spain). Hydrobiologia, 712(1): 5-23.

Jiang W G, Jia K, Wu J J et al., 2015. Evaluating the vegetation recovery in the damage area of Wenchuan Earthquake using MODIS data. Remote Sensing, 7(7): 8757-8778.

Jiang W G, Peng H, Zhu X H et al., 2011. Analysis of vegetation response to rainfall with satellite images in Dongting Lake. Journal of Geographical Sciences, 21(1): 135-149.

Jiang W G, Yuan L H, Wang W J et al., 2015. Spatio-temporal analysis of vegetation variation in the Yellow River Basin. Ecological Indicators, 51: 117-126.

Kearsley L H, Schmidt J C, Warren K D, 1994. Effects of Glen Canyon dam on Colorado River sand deposits used as campsites in Grand Canyon National Park, USA. River Research and Applications, 9(3): 137-149.

Kleinhans M G, Berg J H V D, 2011. River channel and bar patterns explained and predicted by an empirical and a physics-based method. Earth Surface Processes and Landforms, 36(6): 721-738.

Knighton A D, Nanson G C, 1993. Anastomosis and the continuum of channel pattern. Earth Surface Processes and Landforms, 18(7): 613-625.

Li Y B, 2015. Flow-sediment Transport and Riverbed Evolutions of the Middle Reaches of the Yangtze River. Beijing: China Communications Press. (in Chinese)

Li Y T, Sun S H, Deng J Y et al., 2011. Water and Sediment Control Theory and Application of Changjiang River. Beijing: Science Press. (in Chinese)

Luo X X, Yang S L, Zhang J, 2012. The impact of the Three Gorges Dam on the downstream distribution and texture of sediments along the middle and lower Yangtze River (Changjiang) and its estuary, and subsequent sediment dispersal in the East China Sea. Geomorphology, 179(1): 126-140.

Magilligan F J, Nislow K H, 2005. Changes in hydrologic regime by dams. Geomorphology, 71(1): 61-78. 
Mei X F, Dai Z J, Fagherazzi S et al., 2016. Dramatic variations in emergent wetland area in China's largest freshwater lake, Poyang Lake. Advances in Water Resources, 96: 1-10.

Mei X F, Dai Z J, Wei W et al., 2015. Dams induced stage-discharge relationship variations in the upper Yangtze River basin. Hydrology Research, 47(1): 157-170.

Messager M L, Lehner B, Grill G et al., 2016. Estimating the volume and age of water stored in global lakes using a geo-statistical approach. Nature Communications, 7: 13603.

Petts G E, 1979. Complex response of river channel morphology subsequent to reservoir construction. Progress in Physical Geography, 3(3): 329-362.

Phillips J D, Slattery M C, Musselman Z A, 2005. Channel adjustments of the lower Trinity River, Texas, downstream of Livingston Dam. Earth Surface Processes and Landforms, 30(11): 1419-1439.

Provansal M, Dufour S, Sabatier F et al., 2014. The geomorphic evolution and sediment balance of the lower Rhône River (southern France) over the last 130years: Hydropower dams versus other control factors. Geomorphology, 219: 27-41.

Qian N, Wan Z H, 2003. Mechanics of Sediment Transport. Beijing: Science Press. (in Chinese)

Raška P, Dolejš M, Hofmanová M, 2017. Effects of damming on long-term development of fluvial islands, Elbe River (N Czechia). River Research and Applications, 33(4): 471-482.

Sherrard J J, Erskine W D, 1991. Complex response of a sand-bed stream to upstream impoundment. River Research and Applications, 6(1): 53-70.

Skalak K J, Benthem A J, Schenk E R et al., 2013. Large dams and alluvial rivers in the Anthropocene: The impacts of the Garrison and Oahe Dams on the Upper Missouri River. Anthropocene, 2: 51-64.

Soti V, Tran A, Bailly J S et al., 2009. Assessing optical earth observation systems for mapping and monitoring temporary ponds in arid areas. International Journal of Applied Earth Observations and Geoinformation, 11(5): 344-351.

Sun F D, Sun W X, Chen J et al., 2012. Comparison and improvement of methods for identifying water bodies in remotely sensed imagery. International Journal of Remote Sensing, 33(21): 6854-6875.

Tang Z H, Li R P, Li X et al., 2014. Capturing lidar-derived hydrologic spatial parameters to evaluate playa wetlands. Jawra Journal of the American Water Resources Association, 50(1): 234-245.

Tang Z H, Li Y, Gu Y et al., 2016. Assessing Nebraska playa wetland inundation status during 1985-2015 using Landsat data and Google Earth engine. Environmental Monitoring and Assessment, 188(12): 654.

Tran A, Sudre B, Paz S et al., 2014. Environmental predictors of west Nile fever risk in Europe. International Journal of Health Geographics, 13(1): 26.

Ullah S, Skidmore A K, Groen T A et al., 2013. Evaluation of three proposed indices for the retrieval of leaf water content from the mid-wave infrared (2-6 $\mu \mathrm{m})$ spectra. Agricultural and Forest Meteorology, 171: 65-71.

Wang Z Q, Chen Z Y, Li M T et al., 2009. Variations in downstream grain-sizes to interpret sediment transport in the middle-lower Yangtze River, China: A pre-study of Three-Gorge Dam. Geomorphology, 113(3): 217-229.

Wang Z Y, 2009. Integrated Management of Hydro-sediment and Ecology in the Yangtze River Basin. Beijing: Science Press. (in Chinese)

Wei W, Chang Y P, Dai Z J, 2014. Streamflow changes of the Changjiang (Yangtze) River in the recent 60 years: Impacts of the East Asian summer monsoon, ENSO, and human activities. Quaternary International, 336(12): 98-107.

Wright S A, Kaplinski M, 2011. Flow structures and sandbar dynamics in a canyon river during a controlled flood, Colorado River, Arizona. Journal of Geophysical Research: Atmospheres, 116(F1): 132-140.

Wyrick J R, Klingeman P C, 2011. Proposed fluvial island classification scheme and its use for river restoration. River Research and Applications, 27(7): 814-825.

Xia J Q, Deng S S, Zhou M R et al., 2017. Geomorphic response of the Jingjiang Reach to the Three Gorges Project operation. Earth Surface Processes and Landforms, 42(6): 866-876.

Xia J Q, Zong Q L, Zhang Y et al., 2014. Prediction of recent bank retreat processes at typical sections in the Jingjiang Reach after the TGP operation. Science China Technological Sciences, 57(8): 1490-1499. 
Xiong M, Xu Q X, Yuan J et al., 2010. Study of the influences of Three Gorges Project's initial operation on river regime of the middle and lower Yangtze River. Journal of Hydroelectric Engineering, 29(1): 120-125. (in Chinese)

$\mathrm{Xu} \mathrm{H} \mathrm{Q,} \mathrm{2006.} \mathrm{Modification} \mathrm{of} \mathrm{normalised} \mathrm{difference} \mathrm{water} \mathrm{index} \mathrm{(NDWI)} \mathrm{to} \mathrm{enhance} \mathrm{open} \mathrm{water} \mathrm{features} \mathrm{in}$ remotely sensed imagery. International Journal of Remote Sensing, 27(14): 3025-3033.

Xu J X, 1997. Evolution of mid-channel bars in a braided river and complex response to reservoir construction: An example from the middle Hanjiang River, China. Earth Surface Processes and Landforms, 22(10): 953-965.

Xu X B, Tan Y, Yang G S, 2013. Environmental impact assessments of the Three Gorges Project in China: Issues and interventions. Earth-science Reviews, 124(9): 115-125.

Xu K H, Milliman J D, 2009. Seasonal variations of sediment discharge from the Yangtze River before and after impoundment of the Three Gorges Dam. Geomorphology, 104(3): 276-283.

Yang S L, Milliman J D, Li P et al., 2011. 50000 dams later: Erosion of the Yangtze River and its delta. Global and Planetary Change, 75(1): 14-20.

Yang S L, Milliman J D, Xu K H et al., 2014. Downstream sedimentary and geomorphic impacts of the Three Gorges Dam on the Yangtze River. Earth-Science Reviews, 138: 469-486.

Yang S L, Xu K H, Milliman J D et al., 2015. Decline of Yangtze River water and sediment discharge: Impact from natural and anthropogenic changes. Scientific Reports, 5: 12581.

Yang Y P, Zhang M J, Li Y T et al., 2016. Suspended sediment recovery and bedsand compensation mechanism affected by the Three Gorges Project. Acta Geographica Sinica, 71(7): 1241-1254. (in Chinese)

Yu W C, Lu J Y, 2005. River Channel Evolution and Governance of Changjiang River. Beijing: China Water Power Press. (in Chinese)

Yu W C, Lu J Y, 2008. Bank Erosion and Protection in the Yangtze River. Beijing: China Water and Power Press. (in Chinese)

Yuan W H, Yin D W, Finlayson B et al., 2012. Assessing the potential for change in the middle Yangtze River channel following impoundment of the Three Gorges Dam. Geomorphology, 147(8): 27-34.

Zhang W, Yang Y P, Zhang M J et al., 2017. Mechanisms of suspended sediment restoration and bed level compensation in downstream reaches of the Three Gorges Projects (TGP). Journal of Geographical Sciences, 27(4): 463-480.

Zhao Y F, Zou X Q, Gao J H et al., 2015. Quantifying the anthropogenic and climatic contributions to changes in water discharge and sediment load into the sea: A case study of the Yangtze River, China. Science of the Total Environment, 536: 803-812.

Zhu L L, Chen J C, Yuan J et al., 2014. Sediment erosion and deposition in two lakes connected with the middle Yangtze River and the impact of Three Gorges Dam. Advances in Water Science, 25(3): 348-357. (in Chinese) 